\title{
Burning coal spoil heaps as a new habitat for the extremophilic red alga Galdieria sulphuraria
}

\author{
Dovilè BarCyté ${ }^{1, *}$, Linda NedBalovÁ ${ }^{1}$, Adam CulKA ${ }^{2}$, Filip KoŠEK ${ }^{2} \&$ Jan JehličKA ${ }^{2}$
}

\author{
${ }^{1}$ Department of Ecology, Faculty of Science, Charles University, Viničná 7, Prague 2, 128 44, Czech Republic; \\ *Corresponding author e-mail: Dovile Barcyte, dovile.barcyte@gmail.com \\ ${ }^{2}$ Institute of Geochemistry, Mineralogy and Mineral Resources, Faculty of Science, Charles University, Albertov \\ 6, Prague 2, 128 43, Czech Republic
}

\begin{abstract}
Galdieria sulphuraria (Cyanidiales) is a worldwide acclaimed thermoacidophilic red microalga with a limited distribution due to special conditions required for growth and metabolism. Until now, the alga was almost exclusively restricted to acid geothermal environments around the world. However, we have found this species on the surface of a burning coal spoil heap in central Europe. It is the first record of G. sulphuraria in this type of habitat. A $r b c$ L phylogeny confirmed that the population of this extremophile belongs to the continental European lineage and we consider Italian geothermal sites as a potential source of Czech G. sulphuraria. The dispersal of unicellular red microalgae is far from fully understood and the discovery of Galdieria in another region of Europe on a relatively newly established anthropogenic site allows us to understand better the distribution patterns and dispersal abilities of this ecologically important algal group. In addition, we have also analyzed the phylogenetic position of Galdieria strain CCALA 965 isolated from a highly acidic site without geothermal activity in the Czech Republic and confirmed it to belong to the species $G$. phlegrea, until now known only from Italy.
\end{abstract}

Keywords: calmodulin, dispersal, ecology, Galdieria, $r b c \mathrm{~L}$, thermoacidophilic algae

\section{INTRODUCTION}

Unicellular red alga Galdieria (Cyanidiales) is a worldwide known extremophile that thrives in acidic ( $\mathrm{pH} 0.5-4)$ and often high temperature (up to $56{ }^{\circ} \mathrm{C}$ ) environments, which are usually associated with geothermally active regions. For example, it is well known from Italy (Gross et al. 1998; CinigLia et al. 2004; YoON et al. 2006; PINTO et al. 2007), Yellowstone National Park, USA (FERris et al. 2005; SKORUPA et al. 2013), New Zealand (Toplin et al. 2008) and Iceland (CINIGLiA et al. 2014). Rocks and sediments surrounding hot sulphur springs, steaming fumaroles or boiling mud pools are typical habitats for this extremophile (Gross et al. 1998; Gross \& Gross 2002; Ciniglia et al. 2004, 2014; Ferris et al. 2005; YoOn et al. 2006; PInTO et al. 2007; Toplin et al. 2008; SKOrupa et al. 2013; HsIEH et al. 2015). Although Galdieria is found all over the world, its distibution is discontinuous due to special growth and habitat requirements. Therefore, it serves as a good model organism to study dispersal patterns in microorganisms.

Based on molecular phylogenetics, three well supported Galdieria species exist: G. maxima Sentsova, G. sulphuraria (GAldieri) Merola (including two Russian species $G$. partita Sentsova and $G$. daedala SENTSOvA, described based on morphological differences) and G. phlegrea Pinto, Ciniglia, Cascone et Pollio. Contrary to the cosmopolitan species G. maxima and G. sulphuraria, G. phlegrea is known only from Italy where it was found to thrive in highly acidic non-thermophilic sites (CInIGLia et al. 2004, PINTO et al. 2007). Interestingly, before the discovery of the Italian strains of G. phlegrea, Gross et al. (2002) also described a non-thermophilic Galdieria isolated from a diatomite shield in the National Nature Reserve Soos, Czech Republic (Fig. S1). The phylogenetic analysis of the partial $18 \mathrm{~S}$ rRNA gene sequence showed that the strain was distantly related to other Galdieria species and indicated a possibly new Galdieria species from a very acid but non-volcanic habitat (Gross et al. 2002).

Extremely acid environments can originate due to oxidation of sulphide minerals and subsequent formation of sulphuric acid. This can be considered as a natural weathering process, and discharge of acid from mineralized rock complexes containing sulphides or coals is of little importance. However, mining 
activities accelerate the rate of oxidation reactions as large masses of sulphide minerals are exposed to the atmosphere. Moreover, oxidation of coal releases heat, which is further amplified by other exothermic reactions, e.g., oxidation of pyrite $\left(\mathrm{FeS}_{2}\right)$ which is commonly finely dispersed or accumulated in sedimentary rocks or coal mass. Temperature rises when heat dissipation is insufficient, and instead it accumulates until the ignition point of $300{ }^{\circ} \mathrm{C}$ is reached. However, the process of spontaneous combustion is highly complex and it is driven by a number of internal and external factors (KIM 2011). The combustion or thermal decomposition without access of air at temperature up to $1000{ }^{\circ} \mathrm{C}$ generates fumes of various composition but they commonly contain $\mathrm{H}_{2} \mathrm{O}, \mathrm{CO}, \mathrm{SO}_{2}, \mathrm{H}_{2} \mathrm{~S}$ or $\mathrm{NH}_{3}$ (TVRdÝ \& SeJKora 1999). Gaseous substances react with each other or with rock substrate to give rise to new mineral phases, mostly soluble sulphates but rarely also uncommon organic minerals (ŽÁČEK \& SKÁla 2015). $\mathrm{SO}_{2}$ and $\mathrm{H}_{2} \mathrm{~S}$ are combined with atmospheric oxygen and water to form sulphuric acid which is together with weathering of pyrite the main cause of acid water drainage occurring on burning coal heaps (MATÝSEK \& RaClavSKÁ 1999). Moreover, relatively low-temperature vents through which heat and fumes are released, create unusual habitats which, surprisingly, can be accommodated by acid and heat-loving organisms (KoMÁreK \& RosA 1957).

Coal has been mined for over 200 years in central Europe. The extensive mining activities in Ostrava-Karviná Coal Mining District situated in the upper Silesia started in 1776 and lasted till 1992 when the first shutdowns of underground mines began. The region was the most important resource of bituminous coal in the country. Approximately 1.6 billion tonnes of hard coal was mined and almost 0.65 billion tones of waste rock was extracted during the whole existance of a coalfield. Majority of such waste rock was removed from the site, however, $\sim 35 \%$ has been deposited in spoil heaps (Martinec \& Schejbalová 2004). The spoil heap Heřmanice (Fig. 1) situated in the northeastern part of the city of Ostrava (Fig. S1) is among the largest spoil heaps within the Ostrava-Karviná Coal District and is one of the last remaining burning coal spoil heaps in Europe.

We have investigated Heřmanice spoil heap for possible traces of extremophile colonization and we have found Galdieria-like alga occupying this unusual habitat. The aim of this study was to confirm the occurrence of Galdieria in the Czech Republic using molecular tools and to report a new habitat suitable for the alga. For comparison, we have also studied Galdieria strain CCALA 965 isolated from a natural highly acidic non-thermophilic site in the Czech Republic. Based on this comparison, we discuss the ecology, distribution and dispersal of the two Galdieria species.

\section{Material AND Methods}

Sampling site. Heřmanice spoil heap (Fig. 1) was created in 1838 within the first coal mining works in the area. Most of the spoil is derived from the exploitation of Herrmanice mine that was in operation from 1942 to 1993 . The volume of deposited material reaches more than 17 million $\mathrm{m}^{3}$ with the total covered area of 110 ha. The highest point of the heap stands $60 \mathrm{~m}$ above ground level with an average height $30 \mathrm{~m}$ of the whole heap. The first signs of thermal activity were already observed during the 1950s and 1960s. The current underground fire episode probably began after 1995 and it affected the whole southeast part of the heap. Therefore, the extensive remediation of the area was initiated in 2005 by state authorities.

From the geological point of view, the studied locality lies in the NW part of Upper-Silesian Basin which is filled with clastic Upper Carboniferous sediments along with bituminous coal seams. The exploited coal seams stratigraphically belong to the Ostrava Unit which is a succession of periodically repeated fine to coarse-grained sandstone, siltstone, claystone and coal seams. Therefore, the body of Herrmanice heap consists of considerably heterogeneous material varying in grain size. Siltstones to claystones are predominant, sandstone is less frequent. Primary minerals of unaltered waste rocks and coal include clay minerals, quartz, pyrite and carbonates. In thermally active zones secondary conglomerates and porcelanites may occur. The percentage of the residual combustible material in the form of coal fragments or coal mass particles dispersed in associated rocks varies and most frequently ranges from 12 to $20 \%$ (JELÍNEK et al. 2015).

Currently, the site with the most visible effect of underground fires and active fume vents is located on the top of the heap and near slopes (GPS N49 $52^{\prime} 01.52^{\prime \prime}$, E18 18'59.19") (Fig. 1). Here, current studies focus on detection of new occurrences of unusual minerals (sulphates, organic minerals) and their spectroscopic properties (KošEK, unpublished). Very fine-grained coaly material occurs ubiquitous on the surface of the heap and also in the porous spaces of the superficial neoformed sediments. Black clayey matter covers the surface of the heap and rare coarser fragments of shales, graywackes or bituminous coal. Clays represent the most common minerals in the superficial layer $(20 \mathrm{~cm})$ of the heap with occasional fragments of charcoal formed by underground heating.

The surface temperature of fume channels ranges between 200 and $500{ }^{\circ} \mathrm{C}$ in the center of the fumarole zone. The measurements were carried out by a non-contact infrared thermometer (OS423-LS, OMEGA Engineering). Here trees were removed to prevent the spread of the fire on the surface of the heap. Gypsum has been detected in association with low temperature vents and relict remnants of trees. Sulphur, sal ammoniac $\left(\mathrm{NH}_{4} \mathrm{Cl}\right)$, mascagnite $\left(\left(\mathrm{NH}_{4}\right)_{2} \mathrm{SO}_{4}\right)$ and a number of $\mathrm{NH}_{4}-, \mathrm{Fe}_{-}, \mathrm{Al}-$ and $\mathrm{Mg}$-sulphates were found occasionally as a result of the fume activity. With increasing distance from the fumarole zone center, the temperature of fumes decreases and occurrence of vents is mostly limited to relict remnants of trees. Altered residual birch stumps and remnants of the external ex-woody parts of the trees occur now as humified and carbonified blackish relics. They are mostly friable, moist at the contact with water vapor coming from the subsurface vent.

Galdieria strains. We have found and sampled biomass of 
Galdieria from five independent fuming vents located a few meters away from each other (Table S1) in April 2016, while the first biomass from the locality was already brought and freezed in April 2015. The surface temperature of a single vent was measured with a glass thermometer and varied in the range of $50-55{ }^{\circ} \mathrm{C}$. The alga was growing only on organic material, i.e. tree stumps, bark or branches (Fig. 2). The biomass was easily scratched from a surface with a spatula or a pipette to a collection tube or a whole piece of wood was transferred to a zip plastic bag. The $\mathrm{pH}$ of the substrate was measured by soaking wood particles in distilled water and measuring the $\mathrm{pH}$ of the solution with a laboratory $\mathrm{pH}$ meter (WTW inoLab pH 720, Germany). The results ranged from 2 to 3. Similar $\mathrm{pH}$ values were also obtained from a soil extract. Using a small amount of inoculum from the field material, we have established four independent cultures (each from a different spot sampled in 2016) which were grown in a modified Allen's Cyanidium medium (Allen 1959; WatANABE et al. 2000) on heating mats TRIXIE (Heimtierbedarf GmbH \& Co, Jarplund-Weding, Germany) illuminated with an Exo Terra (Rolf C. Hagen Inc.) porcelain clamp lamp with a glow reflector containing an Exo Terra Intense Basking Spot 100 $\mathrm{W}$ bulb. The temperature of the cultivation space varied from 35 to $45^{\circ} \mathrm{C}$ and $\mathrm{pH}$ of the media was adjusted to 2.5 .

One more Galdieria strain isolated from the Czech Republic and preserved at Culture Collection of Autotrophic Organisms (CCALA) under number 965 was also included in this study. The strain was isolated from a mud pool discharging $\mathrm{CO}_{2}$ in the Soos National Nature Reserve situated in the western part of the Czech Republic not far from town Františkovy Lázně (Fig. S1). A detailed physiological characteristic of this strain was provided by Gross et al. (2002). We cultivated this strain in the aforementioned medium and conditions as well as in Q-Cell incubator (PolLab, BielskoBiała, Poland) at $20^{\circ} \mathrm{C}$.
Morphological characterization. Cell morphology of Galdieria strains was investigated using both a Nikon Eclipse E400 light microscope (Nikon Inc., Tokyo, Japan) and Zeiss LSM 880 laser scanning confocal microscope (Zeiss, Jena, Germany) equipped with an Argon laser. We used a $488 \mathrm{~nm}$ excitation line collecting emitted light between 499-597 and $611-759 \mathrm{~nm}$. The images were visualized using Image J 1.50. For transmission electron microscopy (TEM), Galdieria strain from Ostrava was fixed for $24 \mathrm{~h}$ in $2.5 \%$ glutaraldehyde in $0.1 \mathrm{M}$ sodium cacodylate buffer $(\mathrm{pH} 7.2)$ and postfixed in $2 \% \mathrm{OsO}_{4}$ in the same buffer. Fixed cells were dehydrated in a graded ethanol series $(35 \%, 50 \%, 70 \%, 80 \%, 96 \%, 100 \%$ for $15 \mathrm{~min})$, transferred to acetone $(3 \times 100 \%$ for $15 \mathrm{~min})$ and finally embedded in Araldite-Poly/Bed ${ }^{\circledR} 812$ mixture (Polysciences Inc., Hirschberg an der Bergstraße, Germany). Ultrathin sections were cut on a Reichert-Jung Ultracut E ultramicrotome (Wetzlar, Germany) and stained using uranyl acetate and lead citrate. Sections were examined using a JEOL JEM-1011 electron microscope (JEOL Ltd., Tokyo, Japan). Photomicrographs were obtained using a Veleta CCD camera (EMSIS GmbH, Münster, Germany) equipped with image analysis software Olympus Soft Imaging Solution $\mathrm{GmbH}$ (Münster, Germany) and later modified by Inkscape 0.91 (Free Software Foundation Inc., Boston, USA).

DNA isolation and sequencing. Total genomic DNA was extracted from two environmental Ostrava samples (2015 and 2016), four established Galdieria cultures and strain CCALA 965. Algal cells were disrupted using glass beads and DNA was isolated with DNeasy Plant Mini Kit (Qiagen GmbH, Hilden, Germany). PCR was done using PPP Master Mix (Top-Bio s.r.o., Prague, Czech Republic) in a total volume of $25 \mu \mathrm{l}$ in a thermocycler GeneTouch (BioER, Hangzhou, China). Ribulose-1,5-bisphosphate carboxylase/oxygenase large subunit $(r b c L)$ gene was amplified with primers $\mathrm{rC} 475 \mathrm{~F}$

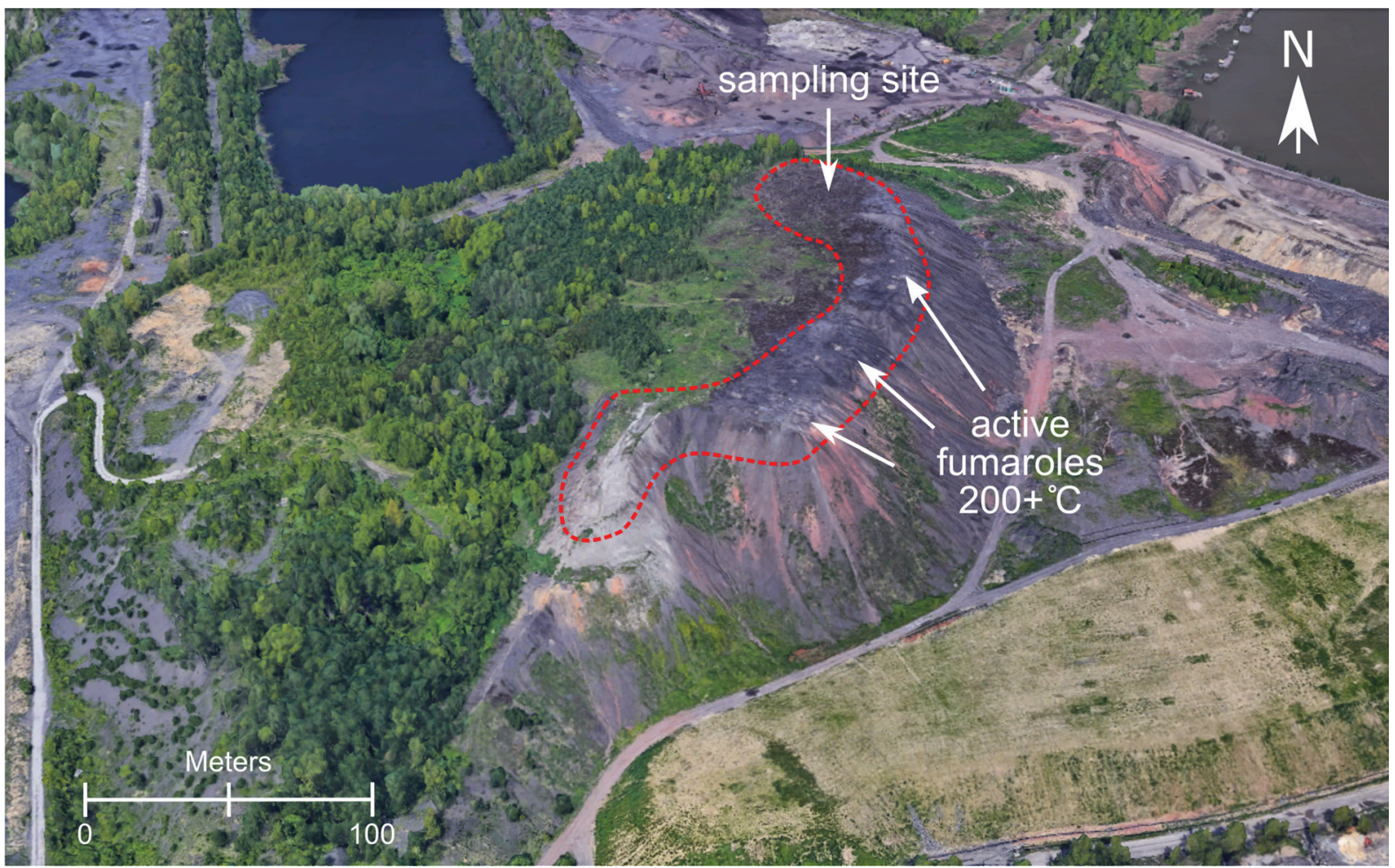

Fig. 1. Sampling site: Heřmanice spoil heap in Ostrava, Czech Republic. 

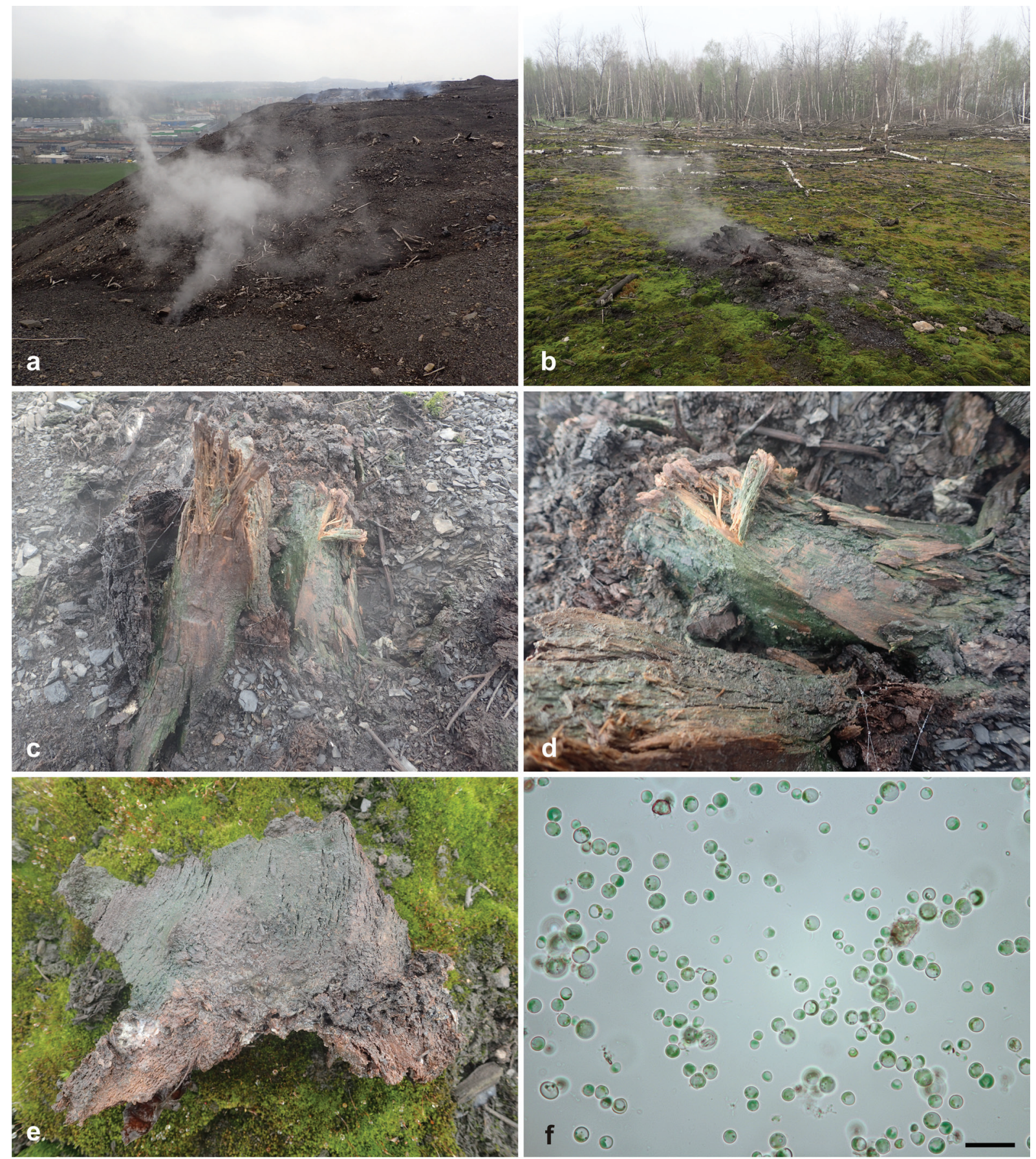

Fig. 2. Sampling site: coal is still burning under the ground (a, b). Galdiera was found growing on the tree residuals (c, d, e) where hot fumes were coming out. Image (f) shows Galdieria cells from the field sample. Scale bar $20 \mu \mathrm{m}$.

and rCR (CInIGLiA et al. 2004). A partial fragment of calmodulin gene $(\mathrm{CaM})$ of environmental Ostrava sample 2015 and strain CCALA 965 was amplified using primers Calmo 140F and Calmo 510R (Yoon et al. 2006). The PCR products were purified with ethanol and sent to Macrogen (Amsterdam, the Netherlands) for sequencing or cloning and sequencing.

Phylogenetic analyses. The $r b c \mathrm{~L}$ and $C a M$ gene sequences were aligned using MAFFT v7 (KATOH \& StANDLEY 2013) available online (http://mafft.cbrc.jp/alignment/software/) and refined manually. The best-fit nucleotide substitution model was estimated with Modeltest 3.7 (PosADA
\& Crandall 1998) in a conjunction with a program PAUP* $4.0 \mathrm{~b} 10$ (SWOFFord 2003). General time reversible model with a proportion of invariable sites and a gamma-shaped distribution of rates across sites $(\mathrm{GTR}+\mathrm{I}+\mathrm{G})$ was selected as the best-fit for the $r b c \mathrm{~L}$ dataset based on Akaike information criterion (AIC). For Bayesian inference (BI) the program MrBayes (Huelsenbeck \& Ronquist 2001) was used. Two MCMC runs for one million generations each with one cold and three heated chains were conducted with trees sampled every 100 generations. Maximum likelihood (ML) analysis was conducted in MEGA7 (KUMAR et al. 2016) with 1000 bootstrap replicates using Nearest-Neighbor-Interchange 
(NNI) heuristic method. Maximum parsimony (MP) was computed using the same software and the same number of bootstrap replicates with Subtree-Pruning-Regrafting (SPR) search method. All sites of the alignment were used in the analyses.

For the CaM data set of G. sulphuraria HasegawaKishino-Yano $(\mathrm{HKY})+\mathrm{I}+\mathrm{G}$ model was selected as the bestfit by hierarchical likelihood ratio tests (hLRTs) while AIC proposed GTR $+\mathrm{I}+\mathrm{G}$ model. However, we have choosen to use HKY model to best match the previuous analysis done by Yoon et al. (2006). For G. phlegrea, we used HKY+G model as it was proposed by AIC. The models were applied both in ML and BI analyses. One million generations with trees sampled every 100 generations were performed for each Bayesian analysis. Bootstrap analyses with 1000 replicates were conducted with ML and MP statistical methods in MEGA7 with the use of all sites in G. sulphuraria case and with partial deletion of missing data in G. phlegrea case and SPR search method was used.

Phylogenetic trees were visusalised with FigTree v1.4.2 (RAMBAUT 2014) and final graphical editing was done in Inkscape v0.91.

\section{RESUlts}

\section{Growth and morphology}

We succeeded to set up a suitable cultivation unit for Galdieria and sustain the growth of the new isolates. Having an optimal growth at about $35{ }^{\circ} \mathrm{C}$ (Gross et al. 2002), the strain CCALA 965 showed a very slow growth while placed at higher temperatures as well as in the incubator at $20^{\circ} \mathrm{C}$.

Galdieria from Ostrava exhibited a typical Cyanidiales morphology: the cells were spherical with a thick cell wall and a blue-green pyrenoidless chloroplast occupying most of the cell volume (Figs $3 \mathrm{a}-\mathrm{c}, 4)$. The TEM investigation confirmed the simple morphology of the cells (Fig. 5). Young cells had a cup-shaped chloroplast (Fig. 5a) whilst in older cells the chloroplast was multi-lobed (Fig. 4; 5b,c) and floridean starch was visible in cytosol (Fig. 5b). Strain CCALA 965 had a very similar morphology and the differences, if any, were indistinguishable using the light microscope (Fig. 3d-f).

\section{Phylogenetic analyses}

This study contained 65 Galdieria sequences of $r b c \mathrm{~L}$ gene together with Porphyra purpurea (DQ418738) and Bangia atropurpurea (AY119770) as outgroup taxa. Genbank accession numbers of all Galdieria sequences included in this study are listed in Table S2. The alignment included 964 bp. The analyzed sequences of Galdieria were primarily divided into two strongly supported clades which correspond to two diffrent Galdieria species: G. sulphuraria and G. phlegrea. G. sulphuraria encompassed sequences from different parts of the world and clustered into seven main and distinct lineages based on their geographical origin (Fig. 6). Other trees conducted by BI and MP analyses were of a very similar topology except that in MP analysis the sequence DBV 135 known from Mexico was placed between North American and Icelandic lineages. All six sequences (4 strains +2 environmental samples) from Ostrava coal mining site were identical and fell within continental European lineage of G. sulphuraria. Strain CCALA 965 was found out to belong to species G. phlegrea (Fig. 6).

Ten CaM clones of Ostrava environmental sample 2015 were selected and subjected to sequencing. The size of the obtained sequences varied from 310$312 \mathrm{bp}$. The clones were aligned with the ones available from Yoon et al. (2006) (Table S2) and the final size of the alignment was 320 positions. The obtained phylogenetic tree (Fig. 7) showed that Galdieria from

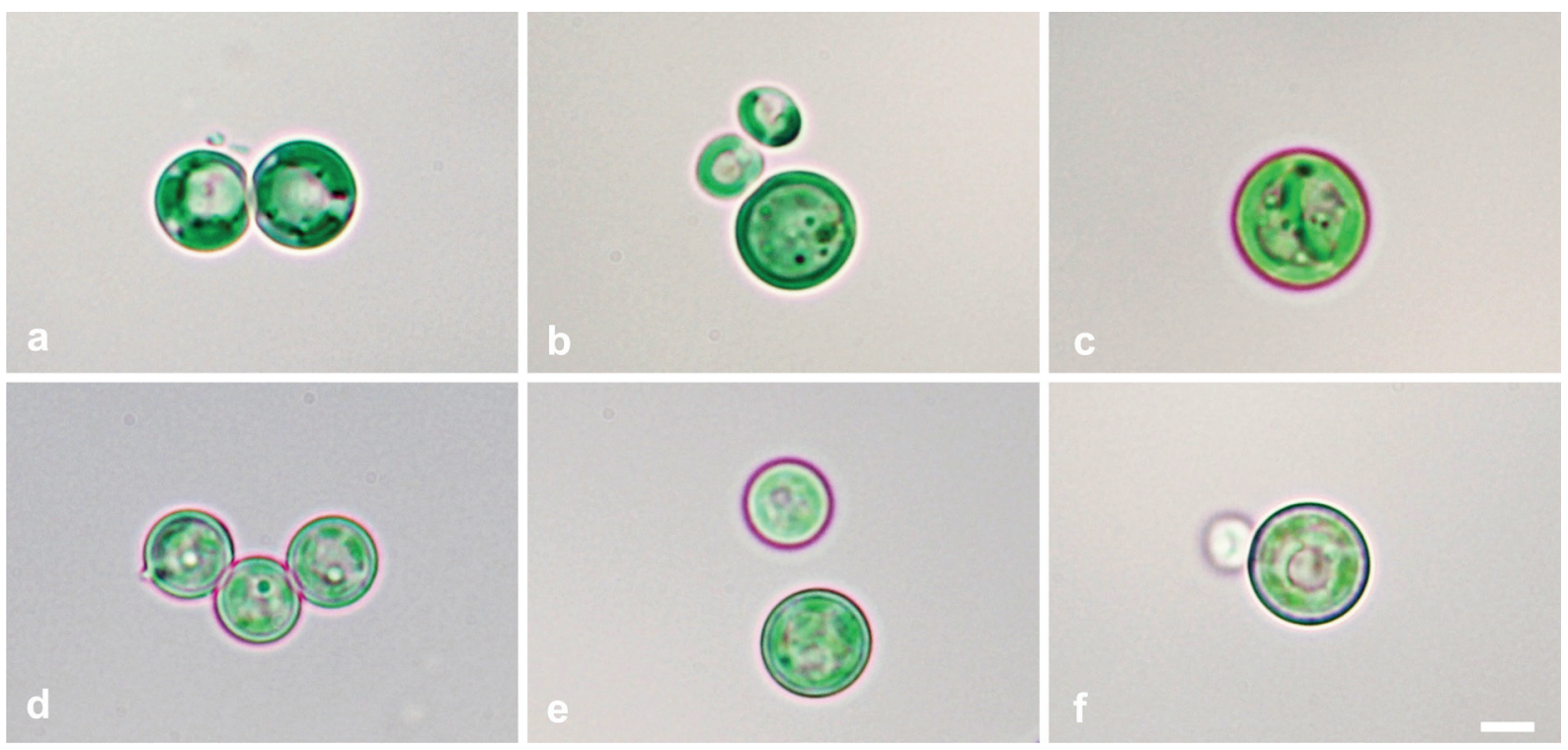

Fig. 3. Morphology of two Galdieria species: (a-c) G. sulphuraria from Ostrava, (d-f) G. phlegrea CCALA 965 from Soos. 
Ostrava forms a distinct population rather than being intermixed with the Italian taxa. However, no bootstrap support was obtained for the whole group. Moreover, deep brantching pattern within Ostrava population was uncovered with two clear sub-groups (Fig. 7).

We also sequenced $336 \mathrm{bp}$ of the partial CaM gene of the strain CCALA 965 and have aligned it with the sequences (385 bp in length) as used in Yoon et al. (2006). Hence, we obtained the phylogenetic tree of almost identical topology (Fig. 8) as in the original paper with few mismatches of little importance. Our analyses supported three $C a M$-based lineages of $G$. phlegrea proposed by Yoon et al. (2006). The strain CCALA 965 clustered within CaM Group A with six Pisciarelli clones and seven clones of a strain DBV 009 from Viterbo (Fig. 8).

\section{Discussion}

Burning coal spoil heaps are extreme habitats in many ways. First of all, the combustion process can mobilize many elements which could be the limiting factor for biodiversity. The content of majority of trace elements in coal seams of Ostrava-Karviná Coal Mining District is considerably lower than the average mean values in hard coal, while the mean concentrations of Ag, Cs, La, $\mathrm{Li}, \mathrm{Pb}, \mathrm{Sr}, \mathrm{As}$ and $\mathrm{W}$ are about by one order higher than
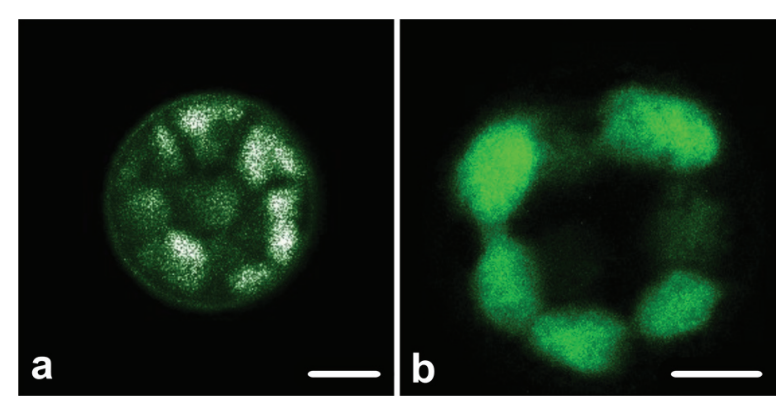

Fig. 4. Multi-lobed chloroplast of G. sulphuraria from Ostrava. Scale bars $3 \mu \mathrm{m}$. the average mean values for bituminous coals (PEŠEK et al. 2010). Under certain conditions, potentially toxic elements can be mobilized from primary phases or coal and can be incorporated in secondary minerals on the surface. Mineral species containing potentially toxic compounds (As, $\mathrm{Se}, \mathrm{Pb}, \mathrm{F}$ ) have been described from burning coal dumps around the world (LAPHAM et al. 1980; ŽÁČEK \& SKÁla 2015). However, no mineralization of this type has previously been observed, neither at Heřmanice dump nor at other burning dumps in this mining district. Therefore, the amount of mobilized toxic elements available for microorganisms in Heřmanice spoil heap can be considered as low and originate mainly from coaly matter. As a result, burning coal spoil heaps can create suitable environment for the thermoacidophilic organisms like Galdieria sulphuraria. For this reason, post-mining sites are important anthropogenic habitats by offering secondary habitats for various organisms, including microalgae. Microbiological studies of these sites have mainly focused on acidophilic bacteria (reviewed in KIRBY et al. 2010) as they are the most numerous organisms there. However, in extremely acid and hot mining areas welladapted Cyanidiales could prevail. Moreover, G. sulphuraria has already been reported from a mining area, i.e. Rio Tinto river contaminated by acid mine drainage in southwestern Spain (MoreIRA et al. 1994; Gross \& Gross 2001). However, until now, there have been no reports of Cyanidiales from burning coal spoil heaps.

Interestingly, Galdieria is usually found growing in endolithic or interlithic habitats (Gross et al. 1998; Ciniglia et al. 2004; Yoon et al. 2006; PinTo et al. 2007), however, in Ostrava site we have found the entire rich population living on the soft substrates as are the residuals of trees. First of all, organic matter can hold water which is crucial for survival and which may be limiting in low water holding capacity having soils of the spoil heaps, especially when the coal is still burning underneath the surface. We have visited the sampling site a day after rain and could easily spot the flourishing Galdieria on every vent through which fumes were coming out. Secondly, G. sulphuraria is capable
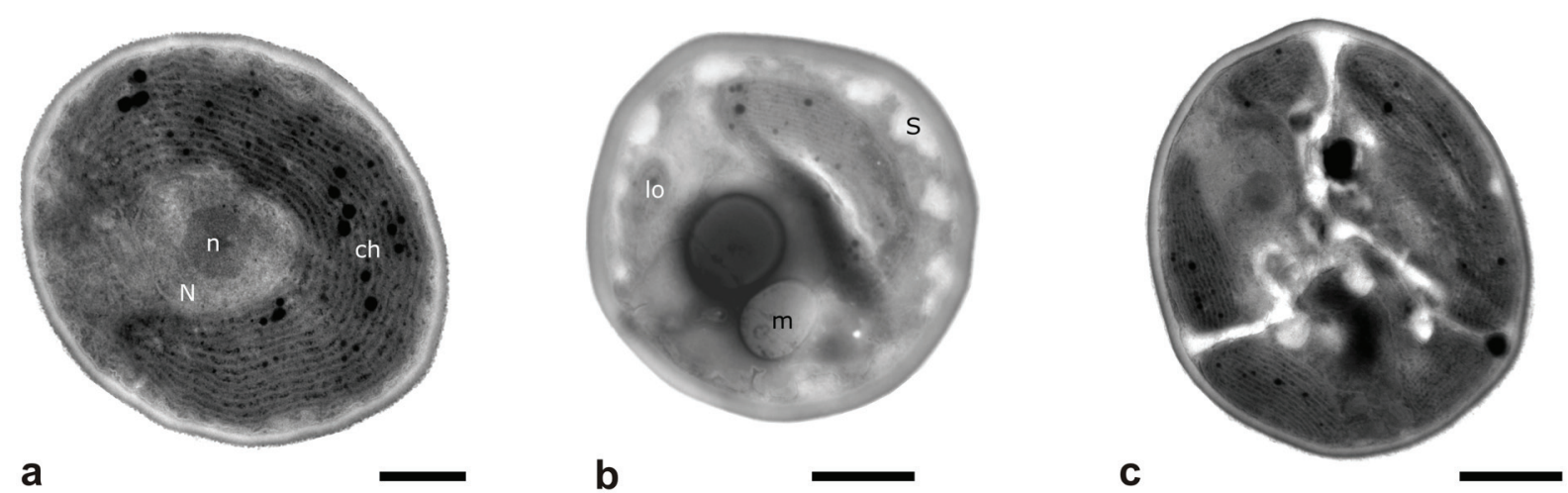

Fig 5. TEM micrographs of Ostrava strain. (a) young cell; (b) old cell; (c) old cell with multi-lobed chloroplast. Abbreviations: (n) nucleus, (nu) nucleolus, (ch) chloroplast, (lo) lobe, (m) mitochondrion, (s) floridean starch. Scale bars a $0.5 \mu \mathrm{m}$; b-c $1 \mu \mathrm{m}$. 
to grow heterotrophically (GROSS \& SCHNARRENBERGER 1995 ) and the direct growth on organic substrate could be beneficial for the alga.

Our phylogenetic analyses of $r b c \mathrm{~L}$ gene showed that Galdieria from Ostrava coal mining site belongs to the cosmopolitan species G. sulphuraria. It is the first record of this species growing in central Europe. Our isolates were closely related to the Italian strains, together forming the continental European lineage of $G$. sulphuraria. A non-thermophilic strain of Galdieria, which was also found in the Czech Republic (Gross et al. 2002), herein referred to as CCALA 965, was shown to belong to the species $G$. phlegrea until now known only from Italy (PINTO et al. 2007) and this affiliation was confirmed by both $r b c \mathrm{~L}$ and $C a M$ phylogienies. Accordingly, we have shown that this species is not endemic to Italy and could be found elsewhere. However, we are not sure if the population of this alga is still existing in the Soos Nature Reserve, which is the original locality of CCALA 965.

Microscopic investigation of Ostrava strains did not reveal any new morphological features of the alga. Moreover, G. sulphuraria and G. phlegrea morphologically look the same and molecular analysis together with habitat preference and growth requirements are thus the primary methods for distinguishing both species. Apparently, G. phlegrea prefers dry endolithic sites with extremely low $\mathrm{pH}(0.5-1.5)$ and relatively low temperatures $\left(25-38^{\circ} \mathrm{C}\right.$ ) (Ciniglia et al. 2004; Pinto et al. 2007), what matches the characteristics of the strain described by Gross et al. (2002). On the contrary, $G$. sulphuraria is found in the environments having a $\mathrm{pH}$ up to 4 and temperatures up to $56^{\circ} \mathrm{C}$. The $\mathrm{pH}$ of the samples was strongly acidic $(\mathrm{pH} \leq 3)$ and the average surface temperature of the fuming vents was $52{ }^{\circ} \mathrm{C}$. However, Galdieria was growing a few to a dozen centimeters above the ground (Fig. 2), so the actual temperature the alga was thriving at was arguably lower.

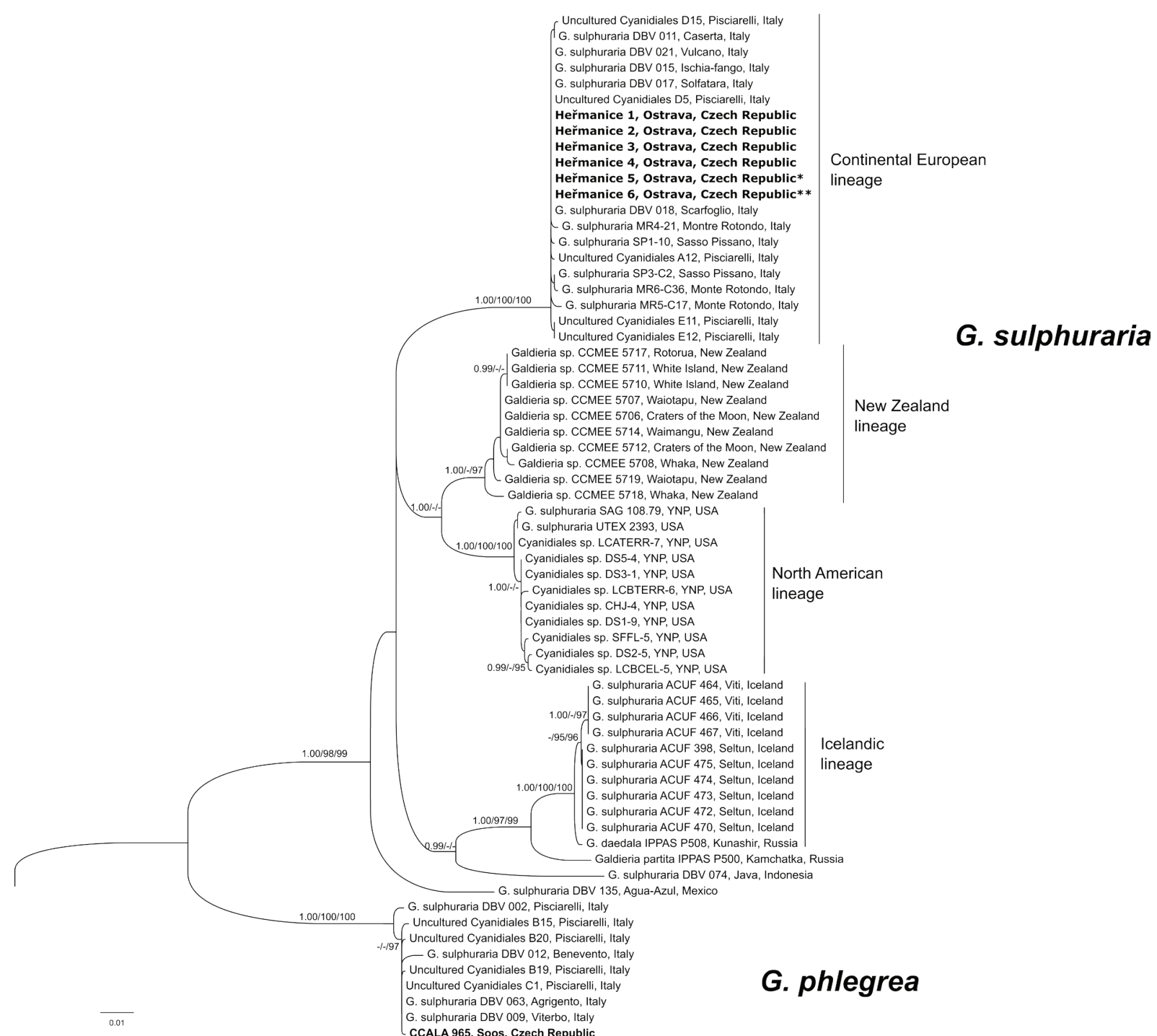

Fig. 6. Phylogenetic tree inferred from maximum likelihood (ML) analysis of $r b c \mathrm{~L}$ gene sequences (with a hidden outgroup). Only Bayesian posterior probabilities $\geq 0.99$ and bootstrap values (ML/MP) $\geq 95 \%$ are shown. Ostrava sequences from environmental samples are marked with asterisks $(* 2016, * * 2015)$. 
Although Galdieria is assumed to have a low desiccation tolerance (SMith \& BRock 1973; Gross et al. 2002) and a long-distance transport could be fatal to the cells, its inoculum was apparently able to overcome the distance between the probable source population in Italy and the Ostrava site in a rather short period of time with anemochory or zoochory as the most probable dispersal modes (Toplin et al. 2008; Ciniglia et al. 2014). For instance, Gross et al. (2001) demonstrated that Galdieria from São Miguel Island (Azores) was most closely related to the strain from Southern Spain, which is the closest geographical site to the island (Gross \& Gross 2002). Moreover, the colonization of new habitats is probably rather quick because the current state of the Ostrava site which could accommodate thermoacidophilic Galdieria has formed only relatively recently. Regarding propagation within the continent, dispersal in patches may also apply for this extremophile. Compared to its counterparts from Cyanidiales, Galdieria is the most flexible and adaptable one (reviewed in Yoon et al. 2006) and could be the most sucessful to establish and sustain its populations where its survival requirements are provided. In addition to that, our study supports a biogeographical pattern of G. sulphuraria (ToPLIN et al. 2008; CinigLiA et al. 2014; Hsien et al. 2015). Moreover, here we demonstrate that it is highly likely that the Italian populations of Galdieria could be the potential source of this extremophile within all central Europe if only suitable habitats for this alga were established. In addition, we speculate that only a small amount of inoculum was enough to colonize Heřmanice spoil heap and develop into an independent population based on $C a M$ sequences and their rather low variability in comparison with the Italian populations.

G. sulphuraria is the only eukaryotic organism forming visible biomass on the burning coal-waste heap of Herrmanice, however, other species of extremophiles might be expected there as well. For example, we have found and molecularly identified an acidophilic and thermotolerant fungus Acidomyces acidothermus (YAmazaKi, ToYAma et NAKAgIRI) Hujslová

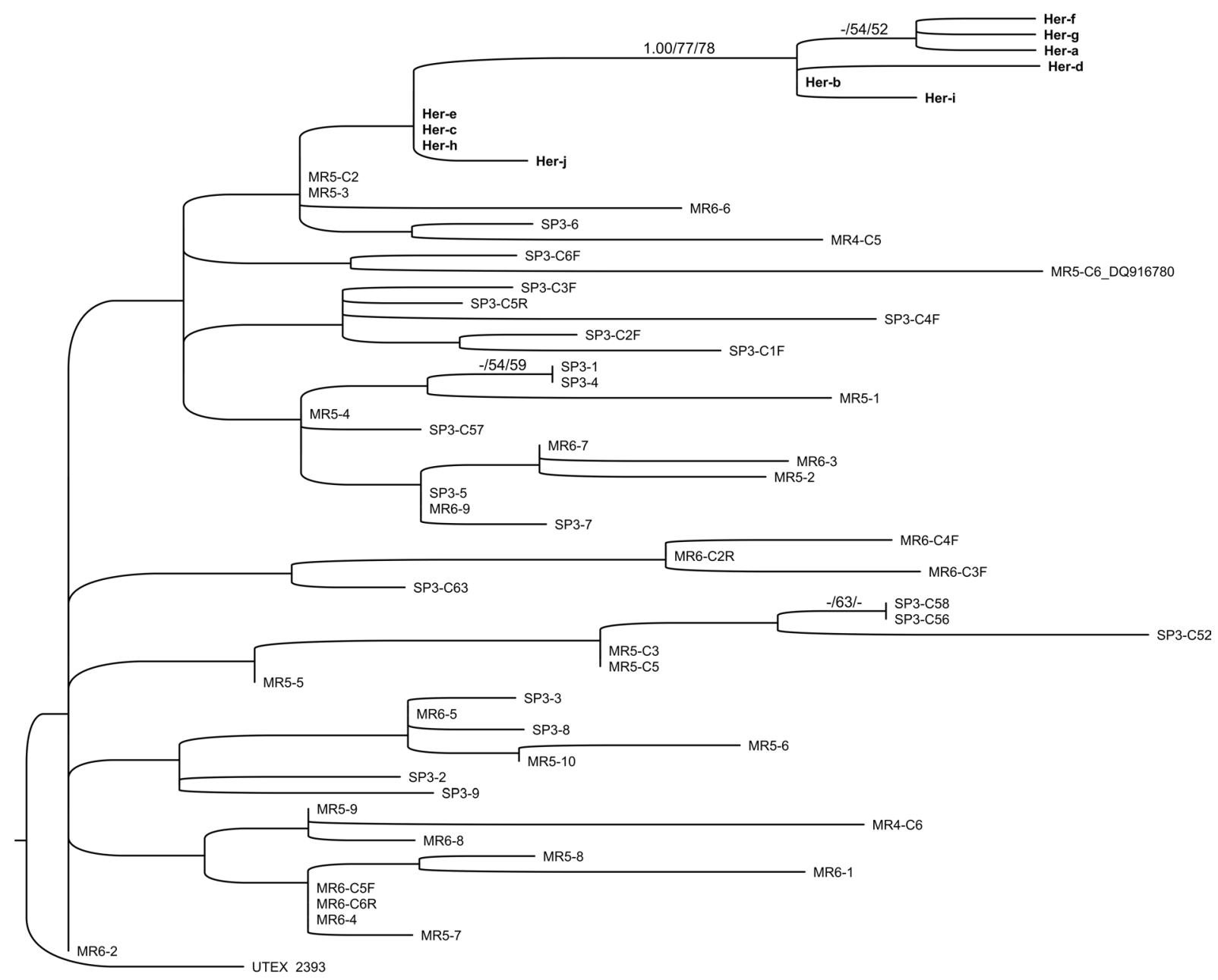

0.005

Fig. 7. Phylogenetic tree of $C a M$ gene of $G$. sulphuraria inferred from ML analysis. Only Bayesian posterior probabilities $\geq 0.99$ and bootstrap values $(\mathrm{ML} / \mathrm{MP})>50 \%$ are shown. New sequences are in bold. MR refers to Monte Rotondo and SP to Sasso Pisano (Larderello, Tuscany, Italy) populations. 
et Kolarík and acid-and-metal-tolerant green alga Coccomyxa onubensis Fuentes, Huss, Montero, Torronteras, Cuaresma, Garbayo et Vílchez so far known only from Rio Tinto river. On the other hand, we have also found and isolated common terrestrial algae such as Chloroidium saccharophilum (KRÜGER) Darienko, Gustavs, Mudimu, Menendez, Schumann, Karsten, Friedl et Pröschold and Chlorococcum sp. MENEGHINI from a fallen tree branch covered by warm fumes. KOMÁREK \& RosA (1957) found cyanobacterium Hapalosiphon (formerly Somerriella) cossyrensis (Borzi) KomÁREK in the spoil heap in Sokolov region, western Bohemia, Czech Republic, in the years when the coal was burning underneath the ground. Interestingly, this species was originally described from Pantelleria Island, Italy, growing on volcanic rocks under which hot water was flowing down. Consequently, burning coal-waste heaps could accomodate a great deal of unique organisms and further investigation of the site could bring interesting results.

Regarding $G$. phlegrea, it has been assumed that the transportability and adpatability of this alga was even more difficult compared with other Galdieria species (CINIGLIA et al. 2014). However, the limitation of habitats which could satisfy ecophysiological needs of the alga and the affiliation to certain type of habitats could play even more important driving factor of the distribution of G. phlegrea. Soos Nature Reserve is a unique place situated in seismic center of the Cheb Basin where magma moves towards the earth's surface (BANKwITZ et al. 2003). The Reserve consits of peat bogs, mineral salt marshes and springs with huge concentrations of different mineral salts. The variety of biotops and habitats in the Reserve was determined not only by specific geological conditions but also by human interventions. Peat was extracted about 70 years ago in the southern part of the Reserve, revealing a layer of diatomaceous earth containing different sulphides, e.g., $\mathrm{FeS}_{2}$. Due to their oxidation, sulphuric acid has accumulated creating an extremely acid environment (Gross et al. 2002). In the middle and south part of the diatomite shield polygonal soil without vegetation

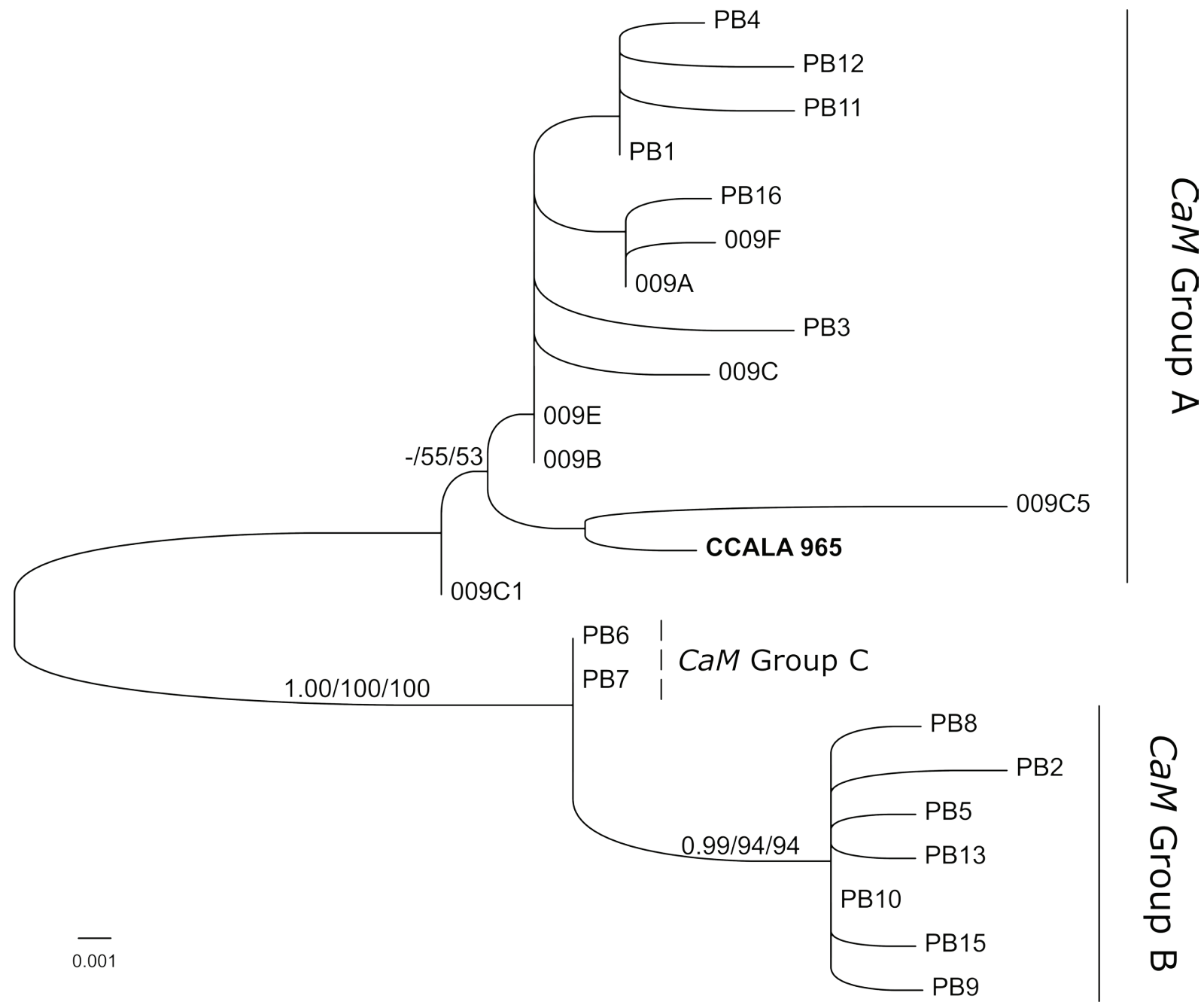

Fig. 8. Phylogenetic tree of CaM gene of G. phlegrea (CCALA 965) inferred from ML analysis. Only Bayesian posterior probabilities $\geq 0.99$ and bootstrap values (ML/MP) $>50 \%$ are shown. PB refers to Pisciarelli population; number 009 to the strain isolated from Viterbo (Italy). See Yoon et al. (2006) 
and extreme acidic $\mathrm{pH}$ is prevailing. In some places $\mathrm{pH}$ varies even from $0-2$. In summer, crystallized salts, e.g., $\mathrm{Na}_{2} \mathrm{SO}_{4}, \mathrm{Na}_{2} \mathrm{CO}_{3} \cdot \mathrm{H}_{2} \mathrm{O}, \mathrm{CaSO}_{4} \mathrm{H}_{2} \mathrm{O}, \mathrm{NaCl}, \mathrm{FeSO}_{4}$, is a common phenomenon on the surface of the soil (HÁJeK \& Vízdal 1998). G. phlegrea was isolated here from a so-called mofette, which is a hole emitting volcanic $\mathrm{CO}_{2}$. An area of approximately $100 \times 80 \mathrm{~m}$ of the Soos Nature Reserve is occupied by mofettes, where gas originates from active magma around $30 \mathrm{ki}$ lometres under the earth's surface and bubbles through the mud pools. The recent study of mofettes done by Beulig et al. (2015) in the neighbouring area of Soos Nature Reserve showed that they could actually promote the soil colonization by acidophilic microorganisms as mofette soil tends to be more acidic than the adjacent ones. Unfortunately, it is very hard to make any conclusions about the actual colonization of Soos Nature Reserve by $G$. phlegrea, but strains belonging to CaM Group A could possibly exhibit a higher tolerance and adaptability for travelling longer distances. However, this could be confirmed or denied only if new strains of the alga were found in the future.

To sum up, in this study we report a new habitat suitable for the thermo-acidophilic red alga G. sulphuraria and contribute to the knowledge about yet poorly understood dispersal of Cyanidiales. We put forward that environmental suitability is the most important factor restricting the occurrence of Cyanidiales.

\section{ACKNOWLedgements}

This work was supported by the Czech Science Foundation (GACR) project P503 14-00227S.

\section{REFERENCES}

Allen, M.B. (1959): Studies with Cyanidium caldarium, an anomalously pigmented chlorophyte. - Arch. Mikrobiol. 32: 270-277.

Bankwitz, P.; Schneider, G.; Kämpf, H. \& Bankwitz, E. (2003): Structural characteristics of epicentral areas in Central Europe: study case Cheb Basin (Czech Republic). - J. Geodyn. 35: 5-32.

Beulig, F.; Heuer, V.B.; Akob, D.M.; Viehweger, B.; Elvert, M.; Herrmann, M.; Hinrichs, K.U.; Küsel, K. (2015): Carbon flow from volcanic $\mathrm{CO}_{2}$ into soil microbial communities of a wetland mofette. - IMSE J. 9: 746-759.

Ciniglia, C.; Yoon, H.S.; Pollio, A.; Pinto, G. \& BhatTACHARYA, D. (2004): Hidden biodiversity of the extremophilic Cyanidiales red algae. - Mol. Ecol. 13: $1827-1838$.

Ciniglia C.; Yang, E.C.; Pollio, A.; Pinto, G.; Iovinella, M.; Vitale, L. \& Yoon, H.S. (2014): Cyanidiophyceae in Iceland: plastid $r b c \mathrm{~L}$ gene elucidates origin and dispersal of extremophilic Galdieria sulphuraria and G. maxima (Galdieriaceae, Rhodophyta). Phycologia 53: 542-551.

Ferris, M.J.; Sheehan, K.B.; KüHL, M.; CoOKsey, K.; Wigglesworth-Cooksey, B.; Harvey, R. \& Henson,
J.M. (2005): Algal species and light microenvironment in a low-pH, geothermal microbial mat community. - Appl. Environ. Microbiol. 71: 7164-7171.

Gross, W. \& Schnarrenberger, C. (1995): Heterotrophic growth of two strains of the acido-thermophilic red alga Galdieria sulphuraria. - Plant Cell Physiol. 36: 633-638.

Gross, W.; Küver, J.; Tischendorf, G.; Bouchaala, N. \& Büsch, W. (1998): Cryptoendolithic growth of the red alga Galdieria sulphuraria in volcanic areas. Eur. J. Phycol. 33: 25-31.

Gross, W. \& Gross, S. (2001): Physiological characterization of the red alga Galdieria sulphuraria isolated from a mining area. - Nova Hedwigia 123: 523-530.

Gross, W. \& Gross, S. (2002): Hot sulphur springs at Sao Miguel Island (Azores): A new locality of the acidophilic red alga Galdieria sulphuraria (Galdieri) Merola. - Algological Studies 107: 109-116.

Gross, W.; Heilmann, I.; Lenze, D. \& Schnarrenberger, C. (2001): Biogeography of the Cyanidiaceae (Rhodophyta) based on $18 \mathrm{~S}$ ribosomal RNA sequence data. - Eur. J. Phycol. 36: 275-280.

Gross, W.; Oesterhelt, C.; Tischendorf, G. \& Lederer, F. (2002): Characterization of a non-thermophilic strain of the red algal genus Galdieria isolated from Soos (Czech Republic). - Eur. J. Phycol. 37: 477-482.

HÁJJK, M. \& Vízdal, P. (1998): Prostorová hydrologická struktura NPR Soos. [Spatial hydrological structure of National Natural Reserve Soos] - In: LeDERER, F. \& CHосHOLOuŠKovÁ, Z. (eds): Flora a vegetace minerálních pramenů a rašeliništ' NPR Soos. - pp. 3-13, ZČU - Pedagogická fakulta, Plzeň.

Hsien, C.J.; Zhan, S.H.; Lin, Y.; TANG, S.L. \& Liu, S.L. (2015): Analysis of $r b c \mathrm{~L}$ sequences reveals the global biodiversity, community structure, and biogeographical pattern of thermoacidophilic red algae (Cyanidiales). - J. Phycol. 51: 682-694.

Huelsenbeck, J.P. \& RonQuist, F. (2001): MRBAYES: Bayesian inference of phylogenetic trees. Bioinformatics 17: 754-755.

Jelínek, P.; Marschalko, M.; Lamich, D.; Yilmaz, I.; Zastěrová, P.; BednÁRIK, M; HeviánKovÁ, S.; KYNCl, M.; Drusa, M. \& RŮČKOVÁ, H. (2015): Monitoring and analysis of burning in coal tailing dumps: a case study from the Czech Republic. - Environ. Earth Sci. 73: 6601-6612.

KIM, A.G. (2012): Coal formation and the origin of coal fires. - In: Stracher, G.B.; Prakash, A. \& Sokol, E.V. (eds): Coal and peat fires: A global perspective, Vol 1, Coal - geology and combustion. - pp. 1-28, Elsevier, Amsterdam.

Kirby, B.M.; Vengadajellum, C.J.; Burton, S.G. \& Cowan, D.A. (2010): Anthropogenically-created habitats coal, coal mines and spoil heaps. In: Timmis, K.N. (ed.): Handbook of hydrocarbon and lipid microbiology. - pp. 2277-2292, Springer, Heidelberg.

KomÁreK, J. \& Rosa, K. (1957): Nález sinice Sommierella cossyrensis Borzi (?) v Čechách. [The discovery of cyanobacterium Sommierella cossyrensis Borzi (?) in Czechia.] - Preslia 29: 17-27.

Kumar, S.; Stecher, G. \& Tamura, K. (2016): MEGA7: Molecular evolutionary genetics analysis version 7.0. for bigger datasets. - Mol. Biol. Evol. 33: $1870-1874$

Lapham, D.M.; Barnes, J.H.; Downey, W.F. \& Finkelman, 
R.B. (1980): Mineralogy associated with burning anthracite deposits in eastern Pennsylvania: Mineral Resource Report 78. - p. 82, Pennsylvania Geological Survey, Harrisburg.

Martinec, P. \& Schejbalová, B. (2004): History and environmental impact of mining in the Ostrava Karviná coal field (upper Silesian coal basin, Czech Republic). - Geol. Belg. 7: 215-223.

Matýsek, D. \& RaclavskÁ, H. (1999): Vznik sulfátové mineralizace na odvalech a její vliv na kvalitu spodních vod v OKR. [The development of sulphate mineralisation in spoil heaps and its effect upon the quality of ground water in Ostrava-Karviná District.] - Uhlí Rudy Geol. Průzk. 6: 8-16.

Moreira, D.; LóPez-Archilla, A.I.; Amils, R. \& Marín, I. (1994): Characterization of two new thermoacidophilic microalgae: genome organization and comparison with Galdieria sulphuraria. - FEMS Microbiol. Lett. 122: 109-114.

Pešek, J.; SÝkorová, I.; Jelínek, E.; Michna, O.; ForstovÁ, J.; MartíneK, K.; VAŠÍČeK, M. \& HaVelcovÁ, M. (2010): Major and minor elements in the hard coal from the Czech upper paleozoic basins. Special Papers No. 20, Czech Geological Survey, Prague.

Pinto, G.; Ciniglia, C.; Cascone, C. \& Pollio, A. (2007): Species composition of cyanidiales assemblages in Pisciarelli (Campi Flegrei, Italy) and description of Galdieria phlegrea sp. nov. - In: Sесквасн, J. (ed.): Algae and Cyanobacteria in Extreme Environments. - pp. 488-501, Springer, Netherlands.

Posada, D. \& Crandall, K.A. (1998): MODElTEST: testing the model of DNA substitution. -Bioinformatics 14: 817-818.

Rambaut, A. (2014): FigTree version 1.4.2. - In: http://tree. bio.ed.ac.uk/software/figtree.

Skorupa, D.J.; Reeb, V.; Castenholz, R.W.; Bhattacharya, D. \& McDermott, T.R. (2013): Cyanidiales diversity in Yellowstone National Park. - Lett. Appl. Microbiol. 57: 459-66.

Smith, D.W. \& BRock, T.D. (1973): The water relations of the alga Cyanidium caldarium in soil. - J. Gen. Microbiol. 79: 219-231.

Swofford, D.L. (2003): PAUP*. Phylogenetic analysis using parsimony (*and other methods). Version 4. Sinauer Associates, Sunderland, Massachusetts.

Toplin, J.A.; Norris, T.B.; Lehr, C.R., McDermott, T.R. \& Castenholz, R.W. (2008): Biogeographic and phylogenetic diversity of thermoacidophilic cyanidiales in Yellowstone National Park, Japan, and New Zealand. - Appl. Environ. Microbiol. 74: 2822-2833.

Tvrdý, J. \& SejKora, J. (1999): Hořící uhelné haldy a redepozice toxických látek při samovolném termickém rozkladu uhelné hmoty. [Burning coal heaps and deposition of toxic compounds during self-ignition of coaly matter.] - EKO 10: 11-15.

Watanabe, M.M.; Kawachi, M.; Hiroki, M. \& Kasai, F. (2000): NIES collection list of strains. Sixth edition, 2000, Microalgae and Protozoa. - 159 pp., Microbial Culture Collections, National Institute for Environmental Studies, Tsukuba, Japan.

Yoon, H.S.; Ciniglia, C.; Wu, M.; Comeron, J.M.; Pinto, G.; Pollio, A. \& Bhattacharya, D. (2006): Establishment of endolithic populations of extremophilic Cyanidiales (Rhodophyta). - BMC Evol. Biol. 6: 78 .
ŽÁČEK, V. \& SKÁLA, R. (2015): Mineralogy of burning-coal waste piles in collieries of the Czech Republic. - In: Stracher, G.B.; Prakash, A. \& Sokol, E.V. (eds): Coal and peat fires: A global perspective, Vol. 3, Case studies - coal fires. - pp. 109-159, Elsevier, Amsterdam.

Supplementary material

the following supplementary material is available for this article:

Table S1. Coordinates of the sampling points.

Table S2. List and accession numbers of sequences analyzed in this study.

Fig. S1. Map of Europe and Czech Republic showing localities where Galdieria was found: Soos Nature Reserve and Herrmanice (a part of the city of Ostrava).

This material is available as part of the online article (http:// fottea.czechphycology.cz/contents)

(C) Czech Phycological Society (2018)

Received March 14, 2017

Accepted June 20, 2017 